\title{
Predicting First-Year Returns Of Health Care IPOs
}

Richard Borghesi, University of South Florida, USA

Tom Pencek, University of South Florida, USA

\begin{abstract}
Prior empirical work shows that IPOs generally earn positive excess first-day returns yet subsequently underperform. Many researchers examine the determinants of post-first-day IPO success, however, these studies do not test for first-year IPO return predictability due to unavailability of pre-IPO data with which to predict first-year performance. In this study we utilize strictly pre-IPO financial data manually obtained from corporate IPO registrations to predict the first-year post-IPO performance of health care firms. We do so by utilizing firm size, free cash flows, discretionary accruals, and Altman's Z. Results suggest that each metric is a significant determinant of first-year raw cumulative and excess cumulative returns, and we are able to reliably identify which firms will be in the top and bottom performance quartiles 30 days, 6 months, and 12 months after the IPO.
\end{abstract}

Keywords: IPO Returns; First Year Performance; Altman's Z; Health Care

\section{INTRODUCTION}

nitial public offerings are a critical means for firms to gain access to needed capital. Typically, in the United States, IPOs begin with the firm choosing an investment bank and then filing an S-1 registration statement with the Securities and Exchange Commission (SEC). This registration contains information regarding the company's history, business model, performance, and a wide range of accounting information. The SEC examines the registration for accuracy and completeness and, if satisfied, declares the offer effective. The investment bank then presents the company to institutional investors. This typically occurs via a road show in which the managers attempt to sell the potential success of the company to those investors. The prospective investors then provide feedback as to their level of interest at a variety of possible offer prices. After gathering this information, the investment bank prices the offer, allocates shares, and exchange trading begins.

Historically, IPOs have been significantly underpriced. That is, in first-day trading share prices tend to rise far above the offer price. First-day returns in the 1990s averaged $21 \%$, and in the early 2000 s averaged $40 \%$ (Ljungqvist, 2007). As billions of dollars have been left on the table, much academic literature has attempted to explain the underpricing phenomenon. The most-well-developed set of literature deals with asymmetric information. For example, Baron (1982) proposes that the investment banker is better informed about the capital market than is the issuer and develops a theoretical model in which the banker is compensated for this informational advantage partly via IPO underpricing. Welch (1989) presents a signaling model in which high-quality firms underprice IPOs in order to obtain a higher price at a seasoned offering. Rock (1986) finds that if there exists a group of investors with information superior to that of the firm and other investors, then the firm must issue underpriced shares to gain the participation of uninformed investors. Benveniste and Spindt (1989) model the IPO process as an auction constructed to induce asymmetrically informed investors to reveal what they know to the underwriter. The end result is underpricing and first-day overperformance.

However, most studies also find that IPOs subsequently significantly underperform. For example, Ritter (1991) finds that the first-day gains are subsequently more than offset by underperformance over the next three years. This finding is consistent with investors being periodically overoptimistic about the earnings potential of young growing companies and firms taking advantage of these windows of opportunity. Additionally, Loughran and Ritter (1995) show that on average IPO firms underperform relative to non-issuing firms for five years after the offering date. 
Another related stream of literature examines the relationship between post-IPO accounting variables and post-IPO performance. For example, Teoh, Welch, and Wong (1998) examine the returns of IPOs in which issuers have unusually high discretionary accruals in the first year after the IPO. They find that those firms that aggressively manage earnings display a three-year aftermarket return of $20 \%$ less than IPO issuers having the most conservative earnings management policies. Chan, Cooney, Kim, and Singh (2008) also examine the effect of discretionary accounting accruals, but do so in conjunction with controls for underwriter reputation and venture capitalist backing. They again find that those firms displaying the most aggressive earnings management underperform those with the most conservative.

However, each of these studies relies on post-IPO financial data to predict post-IPO performance. Thus, there is a vacuum in the literature with respect to predicting the first-year success of IPOs. Further, there exists an array of accounting variables that one could potentially use to attempt to predict first-year IPO returns. Such financial data is contained in the registration or S-1 statement that each IPO firm files with the SEC. In choosing which financial variables to model, in addition to Teoh et al. (1998) we look to Altman (1968) for guidance.

Altman proposes that a particular set of financial ratios are reliable predictors of the financial viability of corporations. Specifically, Altman utilizes working capital/total assets, retained earnings/total assets, EBIT/total assets, market value of equity/book value of debt, and sales/total assets to generate an overall index, Z. These ratios measure liquidity, cumulative profitability, asset productivity, solvency, and sales-generating ability. Altman finds that there are highly significant differences in these ratios between firms that declare bankruptcy and those that do not; those having higher $\mathrm{Z}$ scores are less likely to declare bankruptcy. In essence, Altman's $\mathrm{Z}$ is a measure of overall firm financial health. As such, $Z$ scores may also yield important predictive information regarding post-IPO firm viability and financial performance. ${ }^{1}$ In addition to discretionary accruals and Altman's Z, we also control for firm size and for free cash flows. The latter variable may be important in identifying whether larger free cash flows are associated with greater agency problems (Jensen, 1986) or are instead an indicator of greater firm earning power. In this study we develop regression models that in part utilize discretionary accruals and Altman's $Z$ to predict the first-year returns of health care IPOs. In Section II we discuss our data, in Section III we present results, and conclude in Section IV.

\section{DATA}

We obtain a list of IPOs from hoovers.com, which provides a description of the business operations of each firm that has filed an IPO registration with the SEC. We search through each of Hoover's IPO descriptions and identify all 276 health care-related IPOs from 1997 to 2008. We limit ourselves to a single sector due to constraints in the ability to manually gather data, and choose health-care-related firms because the health care industry represents a large and rapidly growing sector of the US economy. Once health care IPOs are identified, matching by CUSIP we manually obtain associated financial statements using Edgar Online, a service which provides access to each firm's S-1 filing. The S-1 contains the balance sheet, income statement, statement of cash flows, and statement of retained earnings for the vast majority of IPO firms. These financials provide a picture of firm operations before the IPO that may be useful in predicting post-IPO performance.

\section{RESULTS}

We begin by plotting IPO returns in the 3-year post-IPO period (Figure 1). The three variables shown are cumulative IPO returns and excess IPO returns (ER) based on value-weighted and equally-weighted market portfolios. ${ }^{2}$ We see that health care IPOs from $1997-2008$ outperformed the market by a substantial margin on average. The time frame we focus on is within the 12-month post-IPO span. The mean cumulative value-weighted excess returns at the 1-month, 6-month, and 12 -month post-IPO periods are $0.7 \%$. $6.0 \%$, and $7.3 \%$, respectively. However, as Figure 2 illustrates, there are extreme differences between the top and bottom IPO performers during this time. Below we utilize a set of logistic regression models to determine if we can predict whether a firm's returns will fall into the top or bottom quartile of cumulative excess returns.

\footnotetext{
${ }^{1}$ Chava and Jarrow (2004) find that firms most frequently declare bankruptcy two to three years after their IPO.

${ }^{2}$ Returns on value-weighted and equally-weighted market portfolios are obtained directly from the CRSP database.

878 Copyright by author(s) Creative Commons License CC-BY

2013 The Clute Institute
} 


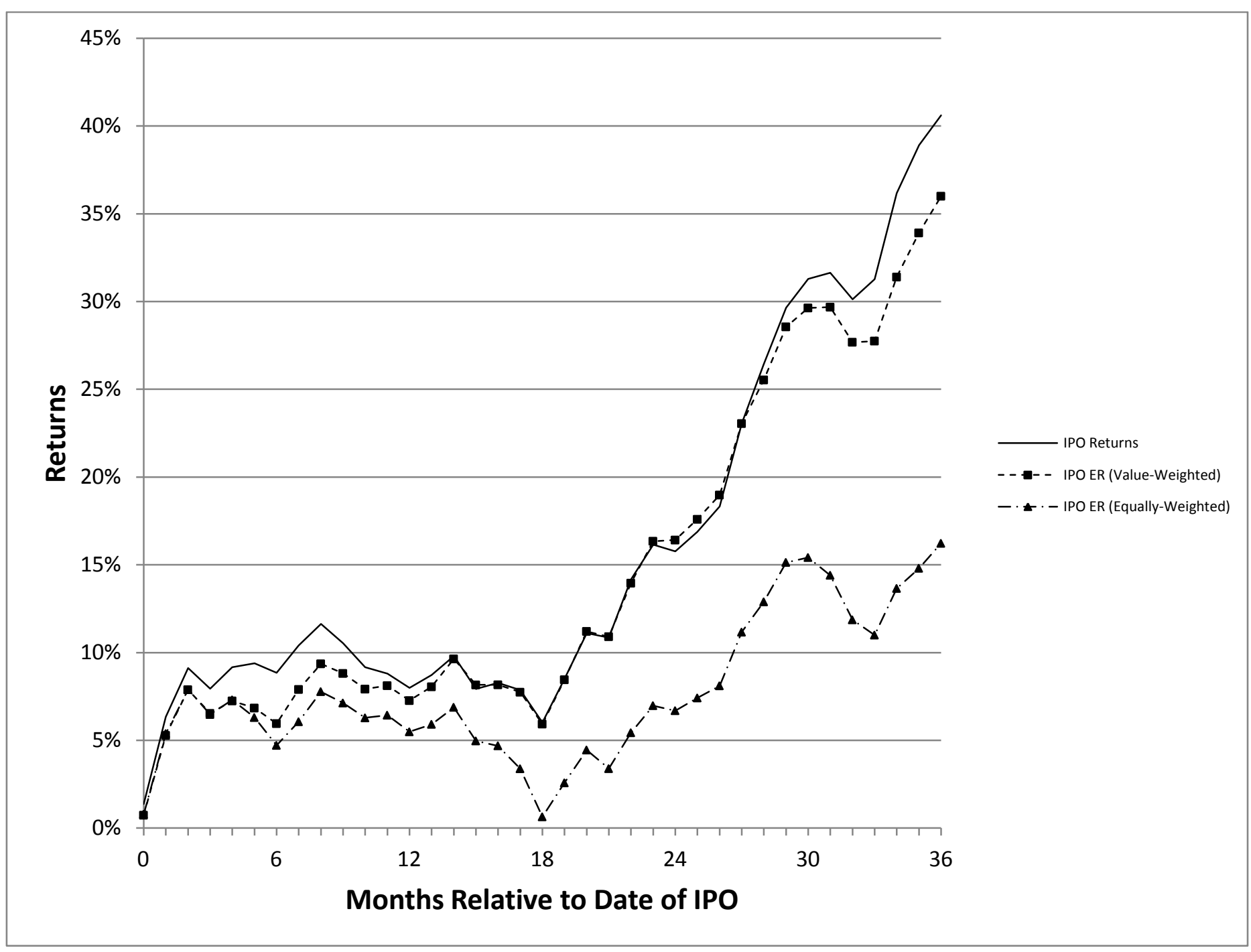

Figure 1 - Cumulative IPO Returns

This figure illustrates cumulative returns for all health-care-related IPOs from 1997 to 2008. The solid line represents the cumulative buy-and-hold return while the dashed lines represent cumulative excess returns (ER) relative to CRSP value-weighted and equally-weighted indexes. 


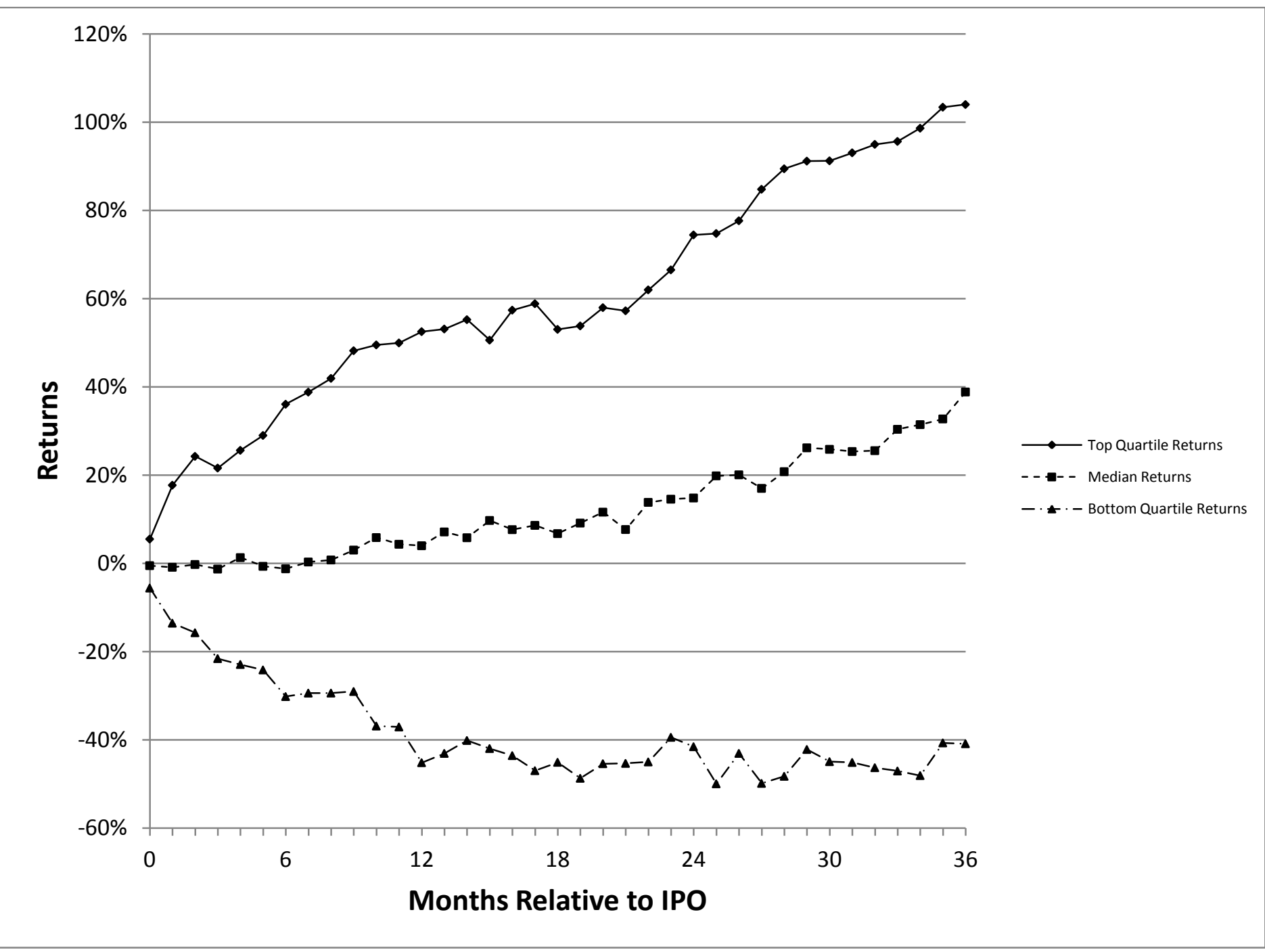

Figure 2 - Cumulative Value-Weighted IPO Excess Return Quartiles

This plot shows the cumulative value-weighed excess IPO returns by quartile. Value-weighted excess returns are calculated as cumulative returns minus CRSP value-weighted market portfolio returns. 
For use in these formal regression analyses, we calculate two potentially important predictive variables Discretionary Accruals and Altman's Z. Prior research by Teoh et al. (1998) and Chan et al. (2008) shows that high discretionary accruals can be a proxy for aggressive earnings management, which is an indicator of poor post-IPO returns. We follow Chan et al. in the construction of this variable and begin by calculating total accruals as:

Total Accruals $=(\triangle C A-\triangle$ Cash $)-(\triangle C L-\triangle S T D-\triangle T P)-D E P$,

where $\triangle C A$ is the change in current assets, $\triangle C$ Cash is the change in cash, $\triangle C L$ is the change in current liabilities, $\triangle S T D$ is the change in short-term debt, $\triangle T P$ is change in taxes payable, and $D E P$ is depreciation and amortization expense. We are forced to omit change in taxes payable, which is generally unavailable in S-1 registration statements.

To control for firm size we next estimate the expression:

$\frac{\text { Total Accruals }_{i}}{T A_{i}}=\alpha_{0} \frac{1}{T A_{i}}+\alpha_{1} \frac{\Delta \text { Sales }_{i}}{T A_{i}}+\alpha_{2} \frac{P P E_{i}}{T A_{i}}+\varepsilon_{i}$,

where $T A$ is the average of beginning and ending total assets, and then use the resulting parameter estimates to predict nondiscretionary accruals $(N D A)$ :

$N D A_{i}=\left(\hat{\alpha}_{0}+\hat{\alpha}_{1} \Delta\right.$ Sales $\left._{i}+\hat{\alpha}_{2} P P E_{i}\right) / T A_{i}$.

Finally, we impute discretionary accruals $(D A)$ is as:

$$
D A_{i}=\left(\text { Total Accruals }{ }_{i}-N D A_{i}\right) / T A_{i} .
$$

Our second derived variable is Altman's $Z$, which is defined as:

$Z=1.2 X_{1}+1.4 X_{2}+3.3 X_{3}+0.6 X_{4}+1.0 X_{5}$,

where $X_{1}$ is working capital/total assets, $X_{2}$ is retained earnings/total assets, $X_{3}$ is earnings before interest expenses and taxes/total assets, $X_{4}$ is market value of equity/book value of total liabilities, and $X_{5}$ is sales/total assets. Because market value of equity is unavailable pre-IPO, we substitute book value of equity in its place.

In addition to $D A$ and Altman's $Z$, we include two fundamental financial variables that are intended to capture the pre-IPO financial disposition of the firm. We chose these variables based on their S-1 availability and subject to the constraints of a test for multicollinearity with DA and Altman's $Z$. The resulting variables include $\log$ Assets, which potentially captures how well-established the firm is prior to its IPO, and Log Free Cash Flows which is an indicator of the ability of the firm to generate cash to sustain operations. The goal is to use the combined set of variables to predict the success of IPOs in the first month, 6 months, and 12 months after issue. Of the initial 276 IPO firms, 35 lack one or more of the desired variables, leaving us with 241 observations.

Results of OLS regressions are shown in Table 1. The dependent variable in Table 1A is Cumulative IPO Returns in the 30 day, 6-month, and 12-month post-IPO periods. Log Free Cash Flows is correlated with 30-day post-IPO returns, indicating the prior ability to generate cash is an important determinant of first-month returns. Looking at the 6- and 12-month regressions, we see that pre-IPO assets are also positively correlated with Cumulative IPO Returns. More importantly, we observe that pre-IPO Discretionary Accruals is negative and significant while pre-IPO Altman's $Z$ is positive and highly significant. The former finding is consistent with Chan et al. (2008) and suggests that firms having managers that attempt to aggressively manage earnings subsequently perform poorly. The latter demonstrates that Altman's $Z$ is not only a reliable predictor of firm bankruptcy, but is also highly correlated with first-year post-IPO returns. As a robustness test we repeat the analysis utilizing Cumulative Value-Weighted Excess IPO Returns as the LHSV and obtain equivalent results (Table 1B). 
Table 1A: Cumulative IPO Returns

This table presents the results of an OLS regression in which the dependent variable is Cumulative IPO Returns. Discretionary Accruals is imputed based on the Chan et al. (2008) model.

\begin{tabular}{|c|c|c|c|c|c|c|}
\hline & \multicolumn{2}{|c|}{ 30-Day } & \multicolumn{2}{|c|}{ 6-Month } & \multicolumn{2}{|c|}{ 12-Month } \\
\hline & Estimate & $p$-Value & Estimate & $p$-Value & Estimate & $p$-Value \\
\hline Intercept & -0.471 & 0.044 & -1.447 & 0.000 & -1.494 & 0.000 \\
\hline Log Assets & -0.001 & 0.967 & 0.034 & 0.086 & 0.038 & 0.037 \\
\hline Log Free Cash Flows & 0.029 & 0.063 & 0.044 & 0.012 & 0.044 & 0.007 \\
\hline Discretionary Accruals & -0.013 & 0.467 & -0.111 & 0.000 & -0.162 & 0.000 \\
\hline Altman's Z & 0.016 & 0.139 & 0.048 & 0.000 & 0.052 & 0.000 \\
\hline r-Square & \multicolumn{2}{|c|}{0.154} & \multicolumn{2}{|c|}{0.176} & \multicolumn{2}{|c|}{0.159} \\
\hline
\end{tabular}

Table 1B: Value-Weighted Excess IPO Returns

This table presents the results of an OLS regression in which the dependent variable is Cumulative Value-Weighted Excess IPO Returns, which represent cumulative IPO returns minus cumulative CRSP value-weighted market portfolio returns.

\begin{tabular}{|c|c|c|c|c|c|c|}
\hline & \multicolumn{2}{|c|}{ 30-Day } & \multicolumn{2}{|c|}{ 6-Month } & \multicolumn{2}{|c|}{ 12-Month } \\
\hline & Estimate & $p$-Value & Estimate & $p$-Value & Estimate & $p$-Value \\
\hline Intercept & -0.288 & 0.213 & -1.268 & 0.000 & -1.471 & 0.000 \\
\hline Log Assets & -0.005 & 0.753 & 0.034 & 0.080 & 0.054 & 0.003 \\
\hline Log Free Cash Flows & 0.023 & 0.137 & 0.034 & 0.054 & 0.023 & 0.160 \\
\hline Discretionary Accruals & 0.000 & 0.998 & -0.092 & 0.000 & -0.140 & 0.000 \\
\hline Altman's $Z$ & 0.013 & 0.203 & 0.038 & 0.001 & 0.044 & 0.000 \\
\hline r-Square & \multicolumn{2}{|c|}{0.112} & \multicolumn{2}{|c|}{0.128} & \multicolumn{2}{|c|}{0.116} \\
\hline
\end{tabular}

Next we utilize a set of logistic regressions to determine whether we can identify those firms that will be in the top vs. bottom quartile of IPO returns. Estimates are presented in Tables 2A (Cumulative IPO Returns) and 2B (Cumulative Value-Weighted Excess IPO Returns). Here we see that in the 6-month and 12-month periods after IPOs, high Free Cash Flows, conservative earnings management, and high Altman's Z are associated with betterperforming firms.

Table 2A: Logistic Cumulative IPO Return Estimates

This table presents the results of a logistic regression in which the dependent variable is Cumulative Returns Quartile, which takes a value of either four or one. The model is constructed such that the probability of returns being in the $4^{\text {th }}$ quartile is predicted.

\begin{tabular}{|c|c|c|c|c|c|c|}
\hline \multirow[b]{3}{*}{ Intercept } & \multicolumn{2}{|c|}{ 30-Day } & \multicolumn{2}{|c|}{ 6-Month } & \multicolumn{2}{|c|}{ 12-Month } \\
\hline & Estimate & $p$-Value & Estimate & $p$-Value & Estimate & $p$-Value \\
\hline & -11.639 & 0.065 & -17.362 & 0.000 & -10.384 & 0.000 \\
\hline Log Assets & -0.181 & 0.661 & 0.197 & 0.400 & -0.038 & 0.830 \\
\hline Log Free Cash Flows & 0.875 & 0.022 & 0.700 & 0.001 & 0.598 & 0.000 \\
\hline Discretionary Accruals & -0.416 & 0.546 & -1.781 & 0.000 & -1.157 & 0.000 \\
\hline Altman's $Z$ & 0.406 & 0.188 & 0.927 & 0.000 & 0.556 & 0.000 \\
\hline
\end{tabular}


Table 2B: Logistic Cumulative Excess IPO Return Estimates

This table presents the results of a logistic regression in which the dependent variable is Cumulative Excess Returns Quartile, which takes a value of either four or one. The model is constructed such that the probability of returns being in the $4^{\text {th }}$ quartile is predicted.

\begin{tabular}{|c|c|c|c|c|c|c|}
\hline \multirow[t]{2}{*}{ 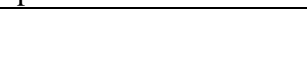 } & \multicolumn{2}{|c|}{ 30-Day } & \multicolumn{2}{|c|}{ 6-Month } & \multicolumn{2}{|c|}{ 12-Month } \\
\hline & Estimate & $p$-Value & Estimate & $p$-Value & Estimate & $p$-Value \\
\hline Intercept & -9.021 & 0.116 & -12.476 & 0.000 & -12.212 & 0.000 \\
\hline Log Assets & 0.101 & 0.774 & 0.130 & 0.594 & 0.316 & 0.083 \\
\hline Log Free Cash Flows & 0.383 & 0.213 & 0.544 & 0.005 & 0.325 & 0.024 \\
\hline Discretionary Accruals & -0.331 & 0.463 & -0.971 & 0.000 & -1.114 & 0.000 \\
\hline Altman's $Z$ & 0.471 & 0.123 & 0.511 & 0.001 & 0.421 & 0.000 \\
\hline
\end{tabular}

The goal is to use these parameters to estimate the probability that each firm's post-IPO returns will be in the top or bottom quartile. We must first estimate $Y_{i}^{*}$, firm $i$ 's predicted returns quartile, and then apply a transformation to predict the probability $\left(\operatorname{Prob}_{i}\right)$ that firm $i$ 's returns will be in the top post-IPO returns quartile. We begin by estimating $Y_{i}^{*}$ as:

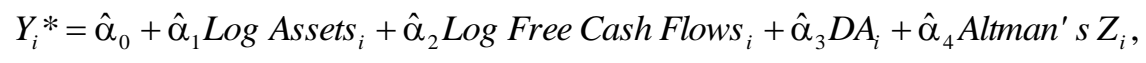

and then utilize the transformation:

$\operatorname{Prob}_{i}=\frac{\mathrm{e}^{Y_{i}{ }^{*}}}{1+\mathrm{e}^{Y_{i}^{*}}}$,

to obtain that probability. When $\operatorname{Prob}_{i}>0.75$, we assign that firm to the top expected performance quartile and when $\operatorname{Prob}_{i}<0.25$ we assign it to the bottom expected performance quartile. We then calculate mean firm returns in each projected quartile and examine whether these two sets of observed returns are significantly different. Test results are presented in Tables $3 \mathrm{~A}$ and $3 \mathrm{~B}$.

Table 3A: Cumulative IPO Return Predictability

This table illustrates the Cumulative IPO Returns of those stocks predicted to be in the $4^{\text {th }}$ and $1^{\text {st }}$ quartile of returns based on the parameter estimates in Table $2 \mathrm{~A}$.

\begin{tabular}{lcccc} 
& First-Month & & 6 -Month & 1-Year \\
\cline { 2 - 3 } Q4 Returns & $7.30 \%$ & $25.37 \%$ & $27.75 \%$ \\
Q1 Returns & $-9.55 \%$ & & $-23.49 \%$ & $-31.94 \%$ \\
Difference & $16.85 \%$ & & $58.84 \%$ & $5.68 \%$ \\
$p$-Value & 0.001 & & 0.001 & 0.001 \\
\hline
\end{tabular}

Table 3B: Cumulative Excess IPO Return Predictability

This table illustrates the Cumulative Value-Weighted Excess IPO Returns of those stocks predicted to be in the $4^{\text {th }}$ and $1^{\text {st }}$ quartile of returns based on the parameter estimates in Table 2B.

\begin{tabular}{lcccc}
\hline & First-Month & & 6 -Month & 1 -Year \\
\cline { 2 - 3 } Q4 Returns & $8.24 \%$ & $13.51 \%$ & $24.93 \%$ \\
Q1 Returns & $-12.86 \%$ & $-28.26 \%$ & $-34.11 \%$ \\
Difference & $21.10 \%$ & $41.77 \%$ & $59.04 \%$ \\
$p$-Value & 0.001 & 0.001 & 0.001 \\
\hline
\end{tabular}

We see that it is possible to identify whether an IPO firm will perform better than its peers based on the utilized pre-IPO variables. Over the first 30-day post-IPO period, the firms in the projected top-performing quartile have a cumulative return of $7.30 \%$ while those in the projected bottom-performing quartile return $-9.55 \%$. The difference of $16.85 \%$ is highly significant. Differences are even more pronounced in the 6-month and 12-month post-IPO periods. Here, we observe that the difference between projected top- and bottom-performers is $48.84 \%$ 
and $59.68 \%$, respectively. Similar results hold for cumulative excess IPO returns as shown in Table 3B. While results are consistent and highly significant, we are cautious in that our dataset includes only IPOs of health-care related firms, and recognize that results may not necessarily generalize to other industries.

\section{CONCLUSION}

In this paper we fill a gap in the extant IPO literature by formulating a method to predict first-year IPO returns utilizing pre-IPO financial data. We begin by examining the first-year returns of health care IPOs and find that on average these IPOs outperform value- and equally-weighted market portfolios. However, within this subset of firms there is a great deal of variability in returns; some significantly outperform while others underperform. We find that after accounting for firm size and free cash flows, those firms that engage in aggressive earnings management by manipulating discretionary accruals tend to underperform.

We also show that Altman's Z, which has previously been used as a determinant of the probability of corporate bankruptcy, is a reliable predictor of first-year post-IPO returns. Utilizing Altman's $Z$ within logistic regression models, we predict the probability that each firm's cumulative raw and cumulative excess returns will be in the top and bottom quartile of all IPO returns. Results show that based on pre-IPO financial information we can identify which firms are likely to be most and least successful after the IPO, and the differences in stock returns between these firms ranges from $16.85 \%$ in the first post-IPO month to $59.68 \%$ in the 12 months following the IPO. While conclusions in this study are limited to health care IPOs, results may generalize, and one opportunity for future research is to expand upon this finding to determine whether Altman's Z is a reliable predictor of IPO returns in other sectors.

\section{AUTHOR INFORMATION}

Richard Borghesi, University of South Florida, College of Business Administration. E-mail: Borghesi@usf.edu (Corresponding author)

Tom Pencek, University of South Florida, College of Business Administration. E-mail: pencek@usf.edu

\section{REFERENCES}

1. Altman, Edward, 1968. Financial Ratios, Discriminant Analysis and the Prediction of Corporate Bankruptcy. The Journal of Finance, 23, 589-609.

2. Baron, David, 1982. A Model for the Demand of Investment Banking Advising and Distribution Services for New Issues. The Journal of Finance, 4, 955-976.

3. Benveniste, Lawrence, and Paul Spindt, 1989. How Investment Bankers Determine the Offer Price and the Allocation of New Shares. Journal of Financial Economics, 24, 343-361.

4. Chan, Konan, John Cooney, Joonghyuk Kim, and Ajai Singh, 2008. The IPO Derby: Are There Consistent Losers and Winners on This Track? Financial Management, 37, 45-79.

5. Chava, Sudheer and Robert Jarrow, 2004. Bankruptcy Prediction with Industry Effects. Review of Finance, 8, 537-569.

6. Jensen, Michael, 1986. Agency Costs of Free Cash Flow, Corporate Finance and Takeovers. American Economic Review, 76, 323-329.

7. Ljungqvist, Alexander, "IPO Underpricing," in Handbooks in Finance, edited by B. Espen Eckbo, (Amsterdam, Netherlands), 2007.

8. Loughran, Tim and Jay Ritter, 1995. The New Issues Puzzle. The Journal of Finance, 50, 23-51.

9. Ritter, Jay, 1991. The Long-Run Performance of Initial Public Offerings. The Journal of Finance, 46, 327.

10. Rock, Kevin, 1986. Why New Issues are Underpriced. Journal of Financial Economics, 15, 187-212.

11. Teoh, Siew, Ivo Welch, and T.J. Wong, 1998. Earnings Management and the Long-Run Market performance of Initial Public Offerings. The Journal of Finance, 53, 1935-1974.

12. Welch, Ivo, 1989. Seasoned Offerings, Imitation Costs, and the Underpricing of Initial Public Offerings, The Journal of Finance, 44, 421-449. 